\title{
Transesterification of camelina sativa oil with supercritical alcohol mixtures
}

\author{
Yingqiang Sun ${ }^{\mathrm{a}, \mathrm{b}}$, Sundaravadivelnathan Ponnusamy ${ }^{\mathrm{b}}$, Tapaswy Muppaneni ${ }^{\mathrm{b}}$ \\ Harvind K. Reddy ${ }^{b}$, Jun Wang ${ }^{b}$, Zheling Zeng ${ }^{a}$, Shuguang Deng ${ }^{a, b, *}$ \\ ${ }^{a}$ Department of Chemical Engineering \\ Nanchang University \\ Nanchang 330031, China \\ ${ }^{\mathrm{b}}$ Department of Chemical \& Materials Engineering \\ New Mexico State University \\ Las Cruces, New Mexico, 88003, USA
}

To be submitted to Energy Conversion and Management (online)

* Corresponding author. Tel.: +1 575646 4346; fax: +1 5756467706 .

E-mail address: sdeng@nmsu.edu (S. Deng) 
The transesterification of camelina sativa oil with methanol - 1-butanol, and

3 ethanol - 1-butanol alcohol mixtures under supercritical conditions have been studied

4 in order to maximize biodiesel yield and improve biodiesel quality. The influence of

5 the variation of the molar ratio of methanol-1-butanol and ethanol-1-butanol from 1:0,

$63: 1,2: 1,1: 1,1: 2$, to $0: 1$ on the yield of free fatty methyl esters/free fatty ethanol esters

7 - free fatty acid butyl esters, the composition of the biodiesel blend mixtures, and the

8 physical properties of the biodiesel have been investigated at the reaction temperature

9 of $290{ }^{\circ} \mathrm{C}$, reaction time of 30 minutes, and the initial reaction pressure of $500 \mathrm{psi}$. A maximum yield of $86.14 \mathrm{wt} \%$ for free fatty acid methyl esters-free fatty acid butyl

11 esters with the optimum cold property can be obtained at the molar ratio of methanol-1-butanol of 0.5-0.9. Also, a maximum yield of $85.60 \mathrm{wt} \%$ for free fatty ethyl esters - free fatty butyl esters with the lowest pour point can be achieved at the molar ratio of ethanol-1-butanol in the range of 0.5-0.7.

Keywords: Camelina sativa oil, biodiesel, alcohol mixtures, transesterification, supercritical conversion 


\section{Introduction}

With the increase of rapid industrialization and population, the energy demands are going to increase from 13.95 terawatt presently to 50 terawatt at the end of this century[1]. The increasing energy demand, petroleum prices, and growing concerns over climate change call for the development of alternative renewable energy sources, such as wind, solar, and biomass [2]. The prospective and problems of renewable energy strategies for sustainable development have been discussed in detail based on the case of Denmark by Hernrik Lund, and a positive conclusion has been given to convert present energy systems into a 100\% renewable energy system [3]. A further study reported the barriers and their solutions of implementation of renewable energy systems in Denmark, which played a representative role in political decision making processes in many countries [4]. It is predicted that biodiesel is going to make up to $80 \%$ of the growth in liquid fuels from 2010 to 2035 in the United States[5]. It is well known that vegetable oils, animal fats, and recycled grease, which are rich in triglyceride have a great potential to be suitable for biofuel production under right processing conditions [6]. Biodiesel is an environmental friendly and renewable fuel. It can be produced using self - catalyzed reactive extraction from germinated oilseed [7]. It is also biodegradable, non - toxic, and has high thermal stability, which is stable in the range of $30-150{ }^{\circ} \mathrm{C}$ [8]. Also, biodiesel can be used in modern unmodified diesel engines [9].Therefore, it is a favorable alternative to conventional energy sources, which will help to decrease the release of greenhouse gas [10]. 
Biodiesel is defined as a fuel composed by mono-alkyl esters of long chain fatty acids from vegetable oils or animal fats [11]. It can be produced by transesterification of short carbon chain alcohol with vegetable oils or animal fats, micro emulsions, and thermal cracking (pyrolysis) [12]. The expensive cost of biodiesel production and competition of food demand with biodiesel production are the limitations for practical use of biodiesel. The right feedstock can significantly reduce the production cost, because of the cost of raw materials accounts for about $60 \%-80 \%$ of the total [13]. Camelina, also known as false flax or gold - of - pleasure, has drawn much attention in the study of biofuel due to its low - input property in culture [13]. It was described as a weed in the United States previously [13], however, it is described as second-generation biodiesel feedstock due to its non-edible feature now [14]. Camelina sativa has a relatively shot growing seasons, and can be cultured on relatively poor and saline soils with little nitride fertilizer [13]. It can be cultured in cold and arid regions, which are not suitable for the culture of food crops [15]. Camelina seeds contain $>40 \%$ oil on a dry weight basis[13], and its oil is rich in Omega - fatty acid. Therefore, their high net energy ratio property, which is reported 2.2 MJ/MJ in west Canada [16], and about 1.47 MJ/MJ in North America [17], makes it a promise feedstock for biodiesel production.

Transesterification as the simplest and economical route to produce biodiesel with a lower viscosity, has been studied in detail previously. Supercritical transesterification reaction is a high reaction rate, high yield, and high purity process. Factors affecting transesterification of camelina oil have been studied dramatically. 
Transesterification kinetics of camelina sativa oil under conventional and microwave heating conditions have been studied and compared, and microwave heating was proved to be an efficient method for transesterification [18]. The transesterification reactions under supercritical and subcritical methanol conditions have been compared, and transesterification under supercritical methanol can get higher biodiesel yield than subcritical methanol conditions [19]. A microreactor with T-shaped junction was used as a continuous flow reactor to optimize biodiesel production from soybean oil [20]. The effect of reaction temperature, reaction time, molar ratio of alcohol/oil and co-solvent to oil ratio on ethanolysis of camelina oil with hexane as a co-solvent have also been reported [15]. For the practical use of alkyl esters, methyl and ethyl esters from camelina oil blend with diesel fuel have been evaluated [9]. The effect of heterogeneous metal oxide catalysts, i.e., $\mathrm{BaO}, \mathrm{SrO}, \mathrm{MgO}$ and $\mathrm{CaO}$, on transesterification of camelina oil with methanol have been investigated, and the relative order of efficiency of catalysts was $\mathrm{BaO}>\mathrm{SrO}>\mathrm{CaO}>\mathrm{MgO}$ [21]. The catalyzed biodiesel production with new catalysts, such as $\mathrm{PA} / \mathrm{NaY}(\mathrm{PA}=$ organic phosphonic acid), was investigated and optimized [22]. Another work studied $\mathrm{KOH}$ modified zirconia as solid base catalyst on biodiesel production from silybum marianum [23]. Hexane as a regular co-solvent for biodiesel production has been studied exhaustively [19]. Carbon dioxide as a co-solvent for biodiesel production from soybean oil has also been reported [24]. The results indicated that hexane and carbon dioxide as co-solvents was favorable to biodiesel yield. 
done, however, many problems are still confronted in the research of biodiesel production by supercritical transesterification. Firstly, the cost of equipment for supercritical transesterification and operation fee is high. The high cost of equipment is due to strict requirement of reaction conditions, such as reaction temperature of $260-350{ }^{\circ} \mathrm{C}[25]$. The high supercritical transesterification operation fee is around $\$ 42,086,302 / \mathrm{yr}$ [25]. Therefore, it is not a viable way for large - scale industrial applications. Secondly, a complete conversion is hard to achieve since transesterification is a reversible reaction [26]. Thirdly, the high pour points of biodiesels from variable feed stocks, such as $-12{ }^{\circ} \mathrm{C}$ of biodiesel from corn oil [27], lower calorific value, cetane number, and oxidation stability are the intractable problems in the practical use of biodiesel [26].

Biodiesel production through transesterification is usually catalyzed by homogeneous or heterogeneous acid and base catalysts [28]. Supercritical methanol, ethanol, and 1-butanol are supposed to act as both reactants and acid catalysts in transesterification processes [29]. The inductive effect of alkyl groups, and the acidities of alcohols are decreasing with the increase of carbon chains, which lead to the decrease of reactivity of methanol, ethanol to 1-butanol with camelina sativa oil. Also, the thermal stability of fatty acid esters is going to decrease with the increase of the length of alkyl chain of esters. Therefore, the variations of reactivity of alcohols and the thermal stability of fatty acid esters make alcohol mixtures a potential reactant to increase the yield of supercritical transesterification products.

The physical properties of biodiesel, such as cold flow property, acid number, 
cetane number, calorific value, and oxidative stability are important factors of biodiesel. The composition of biodiesel and minor components, such as water, free glycerin, free fatty acid, and residual alcohols can significantly affect biodiesel properties [30]. The use of alcohol with longer alkyl chain is proved to be favorable to the cold property of biodiesel, which is reported that butyl esters are $10{ }^{\circ} \mathrm{C}$ lower than methyl esters, and ethyl esters are $2^{\circ} \mathrm{C}$ lower than methyl esters [31].

The main objectives of the current work are to obtain a higher yield of biodiesel with good low-temperature flow property. In this work, transesterification with various supercritical alcohol mixtures have studied and reported in detail. The influence of molar ratio of different alcohol mixtures on transesterification yield have been investigated and reported in this paper. Also, the effect of the variation of the molar ratio of alcohol mixtures on the properties of biodiesel, such as the cetane number, calorific value, and cold property, have been evaluated and presented.

\section{Materials and analysis methods}

The camelina sativa oil purchased from mountain-rose herbs, Eugene, OR consists of 98.3\% triglyceride (TG), and can be used directly for the transesterification with supercritical alcohol mixtures. Methanol $(99.9 \%, v / v)$, ethanol $(\geq 99.5 \%, v / v)$, and 1-butnaol $(\geq 99.4 \%, \quad \mathrm{v} / \mathrm{v})$, directly used alcohols, were all purchased from Sigma-Aldrich for the supercritical transesterification with camelina sativa oil. Since the supercritical temperatures of methanol, ethanol, and 1-butanol are $239{ }^{\circ} \mathrm{C}, 243{ }^{\circ} \mathrm{C}$, to $287{ }^{\circ} \mathrm{C}$, separately, the transesterifications of camelina sativa oil with supercritical 
methanol/ethanol - 1-butanol were carried out at $290{ }^{\circ} \mathrm{C}$ for $30 \mathrm{~min}$ in the PARR 4593 Micro-reactor with a 4843-controller (Parr Instrument Company, Illinois, USA). Molar ratios of methanol/ethanol : 1-butanol were varied from 1:0, 3:1, 2:1, 1:1, 1:2, to $0: 1$ for the study of the effect of molar ratios of alcohol mixtures on compositions and physical properties of blend biofuel. After removal of unreacted alcohols remained in the products by vacuum oven, $8 \mathrm{mg}$ of camelina biodiesels was used for thermos-gravimetric analysis (TGA) performed using Perkin Elmer Pyris 1 TGA. Heptane $(\geq 99.5 \%, \mathrm{GC})$ was used as the solvent for gas chromatography- mass spectrometry (GC-MS) analysis. And the composition of the biodiesel obtained was characterized by the GC-MS system (Agilent, USA) incorporated with an Agilent 5975 C MSD (Triple-Axis Detector) and an Agilent 7890 A GC equipped with a capillary column (HP-5 MS, 5\% phenyl methyl silox $30 \mathrm{~m} \times 250 \mu \mathrm{m} \times 0.25 \mu \mathrm{m}$ nominal).

\subsection{Characteristics of camelina sativa oil}

The quality of camelina sativa oil is expressed in terms of the physicochemical properties such as acid value and saponification value. The saponification value of camelina oil was reported as $193.3(\mathrm{mg} \mathrm{KOH} / \mathrm{g})$. The acid value of camelina oil was found to be $3.2(\mathrm{mg} \mathrm{KOH} / \mathrm{g})$, corresponding to a free fatty acid (FFA) level of $1.58 \%$, which is much lower than the upper limit of FFA content $(3 \mathrm{wt} \%)$ in the oil for transesterification [21]. The camelina sativa oil consisting of $98.3 \%$ triglycerides acids was transesterificated with supercritical alcohols for biodiesel production. The 
viscosity at $40{ }^{\circ} \mathrm{C}$ of camelina sativa oil was determined to be $14.05-15.10 \mathrm{~mm}^{2} / \mathrm{s}$, and the pour point was -23 to $-20{ }^{\circ} \mathrm{C}$, respectively [32].

\subsection{Transesterification of camelina sativa oil with alcohol mixures}

The transesterification of camelina oil with supercritical alcohol mixtures is simulated and presented in Figure 1. Usually, more than the stoichiometry-amount of alcohol mixtures was used to shift the equilibrium to the proposed production side since the transesterification reaction was a reversible reaction. The reactor was initially pressurized to 500 psi in all the experiments.

\section{\{Figure 1\}}

\subsection{Analytical methods}

The camelina biodiesel samples were analyzed by an Agilent 7890A gas chromatograph (GC) incorporated with an Agilent 5975 series mass selective detector (MSD) GC-MS system with a capillary column (DB-23, $60 \mathrm{~m} \times 250 \mu \mathrm{m} \times 0.15 \mu \mathrm{m}$ nominal) for the quantification of reaction products. The contents of biodiesels were calculated quantitatively by the internal standard method. Methyl tricosanoate (C23:0, 99\%), purchase from Sigma Aldrich, is used as the internal standard for the quantification of the compositions of fatty acid butyl esters. Approximately, $1 \mu \mathrm{L}$ sample was injected into the gas chromatograph with helium as the carrier gas. The injection was performed in split mode (10:1). The parameters of the oven temperature program consisted of: starting at $50{ }^{\circ} \mathrm{C}$ with $25^{\circ} \mathrm{C} / \mathrm{min}$ intervals up to $175^{\circ} \mathrm{C}(6 \mathrm{~min})$ and up to $235^{\circ} \mathrm{C}$ with $4{ }^{\circ} \mathrm{C} / \mathrm{min}$ intervals $(5 \mathrm{~min})$. The temperature of the injector and 
169

170

171

172

173

174

detector were set at $235^{\circ} \mathrm{C}$, and the identified compounds of the camelina sativa biodiesels are listed in Table 1(a) and 1(b). The fatty acid esters content was calculated by using the following equation: $\mathrm{C}=\frac{\left(\sum A\right)-A_{E I}}{A_{E I}} \times \frac{C_{E I} \times V_{E I}}{W} \times 100 \%$, where $\sum A$ represents total peak are of fatty acid esters, $A_{E I}$ represents the peak area of internal standard $(\mathrm{C} 23: 0), C_{E I}(\mathrm{mg} / \mathrm{mL})$ is the concentration of internal standard, $V_{E I}$ is the volume of the solution of internal standard, and $\mathrm{W}$ is the total weight of the sample [33]. The weight percentage is calculated using the same method with the total fatty acid content calculation. Thermo-gravimetric analysis (TGA) of camelina oil and camelina biodiesels were performed using Perkin Elmer Pyris 1 TGA. $8 \mathrm{mg}$ of samples were heated from $35^{\circ} \mathrm{C}$ to $850{ }^{\circ} \mathrm{C}$ at a constant heating rate of $10{ }^{\circ} \mathrm{C} / \mathrm{min}$ in a nitrogen atmosphere at a constant purge rate of $20 \mathrm{~mL} / \mathrm{min}$ at the pan.

\section{\{Table 1\}}

\section{Results and discussions}

\subsection{Thermal gravimetric analysis (TGA) of camelina oil biodiesel}

Figure 2 shows the overlay of thermo-gravimetric analysis (TGA) of camelina oil biodiesel obtained from the transesterification of camelina sativa oil with a different molar ratio of alcohol mixtures. The mass percentages remained at specific thermal gravity analysis temperatures are presented in Table 2 . The mass of fatty acid butyl esters (FABE) remains about $90.0 \%$ at $250{ }^{\circ} \mathrm{C}$, while the mass percentages of fatty acid ethyl esters (FAEE) and FABE remain at 77.0\%, 64.0\%, separately. As shown in Figure 2 (a), the slopes of the mass loss curves of fatty acid methyl esters - fatty acid 
190

191

192

193

194

195

196

197

198

199

200

201

202

203

204

205

206

207

208

209

butyl esters (FAME-FABE) are increasing with the increase of the molar ratio of methanol - 1-butanol, which means that the thermal stability of FAME-FABE are decreasing. The same trend was also obtained from the overlay TGA test curves of fatty acid ethanol esters (FAEE) FAEE-FABE mixtures which is shown in Figure 2(b). This is due to the variation of vaporization and decomposition temperatures of the fatty acid esters with different components and the length of the alkyl chain. Biodiesel is proved to be unstable at high temperature and starts to decompose mainly in three types: isomerization reaction to transfer unsaturated fatty acid esters to trans-type fatty acid esters; dimerization or polymerization reactions to form higher molecular weight components; and pyrolysis reactions to break down fatty acid esters to form lower molecular weight esters and hydrocarbons [34]. Usually, fatty acid esters with higher unsaturated degree are easier to cleavage compared with those with a higher saturated degree [35]. With the increase of the molar ratio of the shorter chain alcohols comparing with 1-butanol, the thermal stability of the biodiesel blend is going to decrease due to the high percentage of the FAME/FAEE. Also, since the vaporization point of fatty acid esters increases with the increase of the length of carbon chain, FAME-FABE is much easier to lose weight comparing with FAEE-FABE, which can be observed from slopes of mass lose curve in Figure 2.

\{Figure 2\}

\{Table 2\} 


\subsection{Effect of the molar ratio of Methanol/Ethanol - 1-Butanol on the composition of biodiesel fuel}

Figure 3 shows the influence of the molar ratio of methanol/ethanol - 1-butanol on yield of transesterification of camelina sativa oil with supercritical alcohol mixtures. As we can see from Figure 3, the reaction yield of FABE is about $77 \mathrm{wt} \%$, while the reaction yields of FAME-FABE and FAEE-FABE increase up to 86wt\%, $85 \mathrm{wt} \%$, separately, with the increase of molar ratio of methanol/ethanol - 1-butanol. It indicates that the reaction yields of transesterification of camelina sativa oil with alcohol mixtures increase with the increase of molar ratio of methanol - 1-butanol and ethanol - 1-butanol, however, the yields of FAME-FABE and FAEE-FABE decrease to $82 \mathrm{wt} \%$, and $84 \mathrm{wt} \%$, respectively, after a maximum reaction yield obtained. The positive effect of the increase of the molar ratio of methanol - 1-butanol is due to the following three reasons: Firstly, it is proved that the acidities of methanol, ethanol, and 1-butanol, are decreasing with the increase of carbon chains due to the inductive effect. Secondly, due to the steric effect of the triglyceride and the decrease of the nucleophilicity with the increase of the carbon chain, the reaction rate of methanol with camelina sativa oil will be the fastest, and the transesterification rate of 1-butanol with camelina sativa oil will be the slowest. And thus, with the increase of the molar ratio of methanol-1-buanol, and ethanol-1-butanol, the yield is going to increase caused by the increased reaction rate. Finally, the solubility of the alcohol mixtures of the oil is going to increase with increase of reaction temperature. The thermal properties of the short chain alcohols like water, such as the dielectric constant, 
viscosity, specific gravity, and polarity will be dramatically changed. The concentration of ionic product will be improved by the increasing pressure, and thus supercritical alcohols are also acid catalysts for transesterification [36]. It is beneficial to the production of FAME/FAEE -FABE mixtures. However, there will be a pyrolysis decomposition process of fatty acid esters during the supercritical transesterification, which leads to reduction of production yield [37]. Therefore, the competition of the increased reactivity of alcohol mixtures with pyrolysis of the product led to a maximum yield with a change in the molar ratio of the methanol/ethanol - 1-butanol.

\{Figure 3\}

The composition of the biodiesel obtained was characterized by the GC-MS 7890-5975 system. The fatty acid esters content was calculated by using the following equation: $\mathrm{C}=\frac{\left(\sum A\right)-A_{E I}}{A_{E I}} \times \frac{C_{E I} \times V_{E I}}{W} \times 100 \%$

$\sum A$ is total peak area of fatty acid esters,

$A_{E I}$ is the peak area of internal standard (C23:0),

$C_{E I}(\mathrm{mg} / \mathrm{mL})$ is the concentration of internal standard,

$V_{E I}$ is the volume of the solution of internal standard,

$\mathrm{W}$ is the total weight of the sample.

The weight percentage is calculated using the same method with the total fatty acid content calculation. The total percentages of saturated fatty acid esters and unsaturated fatty acid esters with different amount of double bonds is added together for the comparison of the change of saturated degree of FAME/FAE - FABE. 

transesterification of camelina sativa oil with blend alcohol mixtures. As can be seen from Figure 4(a), the saturated degree is going to increase with the increase of the molar ratio of methanol-1-butanol. The weight percentage of saturated fatty acid esters (C13:0, C16:0, C18:0, C20:0, C22:0) in FAME products is 16.61wt\% initially, and then decreases to $12.17 \mathrm{wt} \%$ when the molar ratio of methanol to 1-butanol is 1:1, and finally, the weight percentage of the saturated fatty acid esters changes to 11.37 $\mathrm{wt} \%$ in FABE. It is supposed that different unsaturation degree of the alkyl groups lead to their different reactivity with alcohols. The composition of the saturated fatty acid butyl esters is going to decrease with the decrease of the molar ratio of methanol saturated alkyl esters comparing to methanol due to its steric effect of the carbon chain. At the same time, the higher unsaturated degree alkyl group have higher reactivity than saturated esters due to the weak electron-withdrawing effect of the unsaturated alkyl group. Therefore, 1-butanol is easier to react with unsaturated alkyl esters. And thus, the percentage of saturated fatty acid esters decreases with the decrease of methanol - 1-butanol molar ratio. As a result, there is an increase of the

272 percentage of unsaturated fatty acid ester in biodiesel products. The increase of the content of unsaturated fatty acids with more than two double bonds will help to improve the combustion of biodiesel with good cold flow property [31]. 
277 Figure 4(b). The weight percentage of saturated fatty acid esters (C13:0, C16:0, C18:0, C20:0, C22:0) in FAEE products is $17.43 \mathrm{wt} \%$ initially, and then decreases to $13.82 \mathrm{wt} \%$

279 when the molar ratio of methanol to 1-butanol is $1: 1$, and finally, the weight percentage of the saturated fatty acid esters changes to 11.37 wt\% in FABE. The increased molar ratio of ethanol - 1-butanol is favorable to the saturated degree of the

FAEE-FABE. And the percentage of the unsaturated composition is increasing with the increase of the percentage of the 1-butanol in reactant due to the lower reactivity of 1-butnaol with triglycerides comparing with methanol.

\subsection{Fuel properties of FAME/FAEE-FABE biodiesel fuels}

The fuel properties of FAME/FAEE-FABE biodiesel fuels are tested and presented in Table 3 (a) and 3(b). The specific gravity, viscosity, calorific value, cetane number, and pour point of the blended biodiesel product is tested and compared with Biodiesel ASTM D6751-08 standard. The specific gravity values fluctuate with the variation of the molar ratio of the reactant. The average specific 291 gravity value of FAME/FAEE - FABE is about 0.92. However, they are still 292 comparable with ASTM D6751-08 standard, which is in the range of $0.87-0.90$. The 293 viscosity is proved to be increased with decrease of molar ratio of methanol/ethanol-1-butanol. The viscosities for FAME-FABE are varied from 5.68 to

$2959.58 \mathrm{~mm}^{2} / \mathrm{s}$ in the range of molar ratio of M-B 3:1 - 1:2, and of $8.15-15.67 \mathrm{~mm}^{2} / \mathrm{s}$ for

FAEE-FABE. They are higher than biodiesel ASTM standard $\left(1.9-6.0 \mathrm{~mm}^{2} / \mathrm{s}\right)$ at 
higher methanol/ethanol- 1-butanol level. The higher viscosity is not favorable to practical use in current engine, however, the problem can be addressed by blending biodiesel with regular diesel or alcohol in practical use [29]. There is a little variation of calorific value of FAME/FAEE-FABE mixtures with the change of molar ratio of alcohol mixtures. The calorific values of FAME-FABE fluctuate in the range of 37.02 - $38.44 \mathrm{MJ} / \mathrm{Kg}$, and of $37.43-38.20 \mathrm{MJ} / \mathrm{Kg}$ for FAEE-FABE. The increase of the length of carbon chain is favorable to calorific value of FAME/FAEE-FABE mixtures, while their pyrolysis during supercritical transesterification process is negative to calorific values of biodiesel products. The interactions of these two factors lead to the variation of calorific values of FAME/FAEE-FABE mixtures. The cetane numbers of FAME/FAEE-FABE mixtures also vary with variation of molar ratio of methanol/ethanol - 1-butanol. The increases of unsaturated degree of biodiesel mixtures and their coherent pyrolysis are supposed to have negative effect on cetane number of biodiesels, while the longer carbon chain is favorable to cetane number. However, they are still comparable to ASTM D6751-08 standard (47 min).

And also, as can be seen from the last column of Table 3, there is a thorough decrease of pour point from -9 to $-17{ }^{\circ} \mathrm{C}$ of biodiesel products with the decrease of molar ratio of methanol-1-butanol and ethanol-1-butanol, which means the cold flow property has been improved due to the increase of their major parameters, such as the length of alkyl chain [26], and the unsaturated degree [39]. Figure 5(a) show the contour of the yield FAME-FABE versus pour point, molar ratio of methanol-1-butanol, and Figure 5(b) show the contour of the yield of FAEE-FABE 
versus pour point, and molar ratio of ethanol-1-butanol. The maximum yield of 86.14 wt $\%$ for the FAME-FABE with pour point of $-12{ }^{\circ} \mathrm{C}$ can be obtained at the molar ratio of methanol-1-butanol of 0.5-0.9, also a maximum yield of the FAEE-FABE of 85.60 wt\% with the lowest pour point of $-14{ }^{\circ} \mathrm{C}$ can be achieved at molar ratio of ethanol-1-butanol in the range of 0.5-0.7.

Though the specific gravity, viscosity, calorific value, cetane number, and pour point of the blended biodiesel products have been tested and reported in this manuscript, however, the total acid number (TAN) as an important parameter to determine the safety property for storage and transportation of blended biodiesel product has not been characterized [39].

\section{\{Table 3\}}

$\{$ Figure 5\}

\section{Conclusions}

In this work, the transesterification of camelina sativa oil with various supercritical alcohol mixtures have studied and reported in detail. The influence of the molar raito of methanol/ethanol-1-butanol on the reaction yield and the physical property have been investigated. A higher yield of biodiesel with good low-temperature flow property is obtained with the variation of the methanol/ethanol-1-butanol. The results prove that, initially, there is a synergistic effect of alcohol mixtures as the reactant for the transesterification with camelina sativa oil, however, the competition of the synergistic effect with the decomposition 
of the product during the supercritical reaction process led to the maximum reaction yield with the variation of the molar ratio of the alcohol mixtures. There is a negative effect of the increase of the molar ratio of the methanol/ethanol-1-butanol on the viscosity of the FAME/FAEE-FABE product, which is not suitable for the practical use of the biodiesel in a current engine. However, the blend of the biodiesel with original fuel is supposed to be a promising solution for its high viscosity. The influence of the variation of the molar ratio of the alcohol mixtures on the properties of the biodiesel, such as the cetane number, calorific value, and pour point have been evaluated and presented. It is indicated that the variation of the length of the alkyl group and the unsaturated degree have little effect on the cetane number and the calorific value. However, there is a favorable effect of the increase of the molar ratio of the 1-butnaol in alcohol mixtures on the cold flow property. According to the contours showing in Figure 5, The maximum yield of 86.14 wt $\%$ for the FAME-FABE with pour point of $-12{ }^{\circ} \mathrm{C}$ can be obtained at the molar ratio of methanol-1-butanol of 0.5-0.9, also a maximum yield of the FAEE-FABE of $85.60 \mathrm{wt} \%$ with the lowest pour point of $-14{ }^{\circ} \mathrm{C}$ can be achieved at molar ratio of ethanol-1-butanol in the range of 0.5-0.7.

\section{Acknowledgments}

This project was partially supported by US Department of Energy (DE-EE0003046, DE-EE0006316), National Science Foundation (EEC-1028968, IIA-1301346), and "The Jiangxi provincial 555 talent program of China” (S. Deng). 


\section{References}

363

364

365

366

367

368

369

370

371

372

373

374

375

376

377

378

379

380

381

382

[1] Tahir M, Amin NS. Recycling of carbon dioxide to renewable fuels by photocatalysis: Prospects and challenges. Renew Sust Energ Rev. 2013;25:560-79.

[2] Balat M. Potential alternatives to edible oils for biodiesel production - A review of current work. Energy Convers Manage. 2011;52:1479-92.

[3] Lund H. Renewable energy strategies for sustainable development. Energy. 2007;32:912-9.

[4] Lund H. The implementation of renewable energy systems. Lessons learned from the Danish case. Energy. 2010;35:4003-09.

[5] Krohn BJ, Fripp M. A life cycle assessment of biodiesel derived from the "niche filling" energy crop camelina in the USA. Appl Energy. 2012;92:92-8.

[6] Wang H, Yan S, Salley SO, and Simon Ng KY. Support effects on hydrotreating of soybean oil over NiMo carbide catalyst. Fuel. 2013;111:81-7.

[7] Gu H, Jiang W, Zhou L, and Gao J. Reactive extraction and in situ self-catalyzed methanolysis of germinated oilseed for biodiesel production. Energ Environ Sci. 2010;4: 1337-44.

[8] Oliveir Zech PB, Palatzky P, Touraud D, Kunz W. Biodiesel, a sustainable oil, in high temperature stable microemulsions containing a room temperature ionic liquid as polar phase. Energ Environ Sci. 2010;3:846-51.

[9] Moser BR, Vaughn SF. Evaluation of alkyl esters from Camelina sativa oil as biodiesel and as blend components in ultra low-sulfur diesel fuel. Bioresour Technol. 
[10] Cherubini F, Bird ND, Cowie A, Jungmeier G, Schlamadinger B, Woess-Gallasch S. Energy- and greenhouse gas-based LCA of biofuel and bioenergy systems: Key issues, ranges and recommendations. Resour Conserv Recy. 2009;53:434-47.

[11] Yusuf N.N.A.N., Kamarudin S.K., Yaakub Z. Overview on the current trends in biodiesel production. Energy Convers Manage. 2011;52:2741-51.

[12] Abbaszaadeh A, Ghobadian, Omidkhah MR, Najafi G. Current biodiesel production technologies: A comparative review. Energy Convers Manage. 2012;63:138-48.

[13] Shukla V.K.S., Dutta PC, and Artz W.E.*. Camelina oil and its unusual cholesterol content. J AM Oil Chem Soc. 2002;79.

[14] Luque R*, Lovett JC*, Datta Bi*, Clancy J, Campelo JM, Romero AA. Biodiesel as feasible petrol fuel replacement: a multidisciplinary overview. Energ Environ Sci. 2010;3:1706-21.

[15] Muppaneni T, Reddy HK, Patil PD, Dailey P, Aday C, Deng S. Ethanolysis of camelina oil under supercritical condition with hexane as a co-solvent. Appl Energy. 2012;94:84-8.

[16] Patrick M, Amit K. Development of emission parameteres and net energy ratio for renewable diesel from canola and camelina. Energy. 2013;58:426-37.

[17] Patil PD, Gude VG, Camacho LM, Deng S. Microwave-assisted catalytic transesterification of camelina sativa oil. Energy Fuels. 2010;24:1298-304.

[18] Patil P, Gude VG, Pinappu S, Deng S. Transesterification kinetics of camelina 
sativa oil on metal oxide catalysts under conventional and microwave heating conditions. Chem Eng J. 2011;168:1296-300.

[19] Patil P, Gude VG, Deng S. Transesterification of camelina sativa oil using supercritical and subcritical methanol with co-solvents. Energy Fuels. 2010;24:746-51. [20] Rahimi M, Aghel B, Alitabar M, Sepahvand A, Ghasempour HR. Optimization of biodiesel production from soybean oil in a microreactor. Energy Convers Manage. 2014;79:599-605.

[21] Patil PD, Deng S. Transesterification of camelina sativa oil using heterogeneous metal oxide catalysts. Energy Fuels. 2009;23:4619-24.

[22] Liu W, Yin P, Zhang J, Tang Q, Qu R. Biodiesel production from esterification of free fatty acid over PA/NaY solid catalyst. Energy Convers Manage. 2014;82:83-91.

[23] Takase M, Zhang M, Feng W, Chen Y, Zhao T, Cobbina SJ, Yang L, Wu X. Application of zirconia modified with $\mathrm{KOH}$ as heterogeneous solid base catalyst to new non-edible oil for biodiesel. Energy Convers Manage. 2014;80:117-25.

[24] Yin JZ, Xiao M, Song JB. Biodiesel from soybean oil in supercritical methanol with co-solvent. Energy Convers Manage. 2008;49:908-12.

[25] Marchetti JM. Influence of economical variables on a supercritical biodiesel production process. Energy Convers Manage. 2013;75:658-63.

[26] Rosie CC, Ruiz JR, Ramos MJ, Pérez Á. Biodiesel from Camelina sativa: A comprehensive characterisation. Fuel. 2013;105:572-7.

[27] Rasimoglu N, Temur H. Cold flow properties of biodiesel obtained from corn oil.

Energy. 2014; 68:57-60 
[28] Banerjee M, Dey B, Talukdar J, Kalita MC. Production of biodiesel from sunflower oil using highly catalytic bimetallic gold-silver core-shell nanoparticle. Energy. 2014; 69:695-9.

[29] Muppaneni T, Reddy HK, Ponnusamy S, Patil PD, Sun Y, Dailey P, et al. Optimization of biodiesel production from palm oil under supercritical ethanol conditions using hexane as co-solvent: A response surface methodology approach. Fuel. 2013;107:633-40.

[30] Wang H, Tang H, Salley S, Simon Ng KY. Analysis of sterol glycosides in biodiesel and biodiesel precipitates.

[31] Warabi Y, Kusdiana D, Saka S. Biodiesel fuel from vegetable oil by various supercritical alcohols. Appl Biochem Biotechnol. 2004;113-116:793-801.

[32] Sun Y, Reddy HK, Muppaneni T, et al. A comparative study of direct transesterification of camelina oil under supercritical methanol, ethanol and 1-butanol conditions. Fuel. 2014;135:530-6.

[33] Ma F, Clements D, Hanna MA. The effects of catalysts, free fatty acids, and water on transesterification of beef tallow. Transactions of the ASAE. 1998;41:1261-4.

[34] Lin R, Zhu Y, Tavlarides LL. Effect of thermal decomposition on biodiesel viscosity and cold flow property. Fuel. 2014;117:981-8.

[35] Anitescu G, Bruno TJ. Biodiesel Fuels from Supercritical Fluid Processing: Quality Evaluation with the Advanced Distillation Curve Method and Cetane Numbers. Energy Fuels. 2012;26:5256-64. 
449 [36] Gude VG, Grant GE. Biodiesel from waste cooking oils via direct sonication. 450 Appl Energy 2013;109:135-44.

451 [37] Demirbas A. Biodiesel fuels from vegetable oils via catalytic and non-catalytic 452 supercritical alcohol transesterifications and other methods: a survey. Energy Convers 453 Manage. 2003;44:2093-109.

454 [38] Ramírez-Verduzco LF, Rodríguez-Rodríguez JE, Jaramillo-Jacob ADR. 455 Predicting cetane number, kinematic viscosity, density and higher heating value of 456 biodiesel from its fatty acid methyl ester composition. Fuel. 2012;91:102-11.

457 [39] Wang H, Tang H, Wilson J, Salley SO, Simon Ng KY. Total acid number 458 determination of biodiesel and biodiesel blends. J AM Oil Chem Soc. $459 \quad 2008 ; 85: 1083-86$. 


\section{List of Figures}

Figure 1. Schematic of transesterification of camelina sativa oil with supercritical alcohols.

Figure 2. Thermo-gravimetric analysis (TGA) curves for camelina biodiesel fuels obtained from different methanol - 1-butanol (a), and ethanol - 1-butanol molar ratios $(b)$.

Figure 3. The influence of molar ratio of methanol/ethanol - 1-butanol on the yield of biodiesel fuel. (The reaction conditions are: reaction temperature of $290{ }^{\circ} \mathrm{C}$, reaction time of $30 \mathrm{~min}$, and initial reaction pressure of $500 \mathrm{psi}$ )

Figure 4. The composition of biodiesel fuel produced from the transesterification of camelina sativa oil with various methanol - 1-butanol alcohol (a), and methanol - 1-butanol alcohol mixtures (b). (The reaction conditions are: the reaction temperature of $290{ }^{\circ} \mathrm{C}$, reaction time of $30 \mathrm{~min}$, and the initial reaction pressure of 500 psi. )

Figure 5. (a) Contour Plot of Yield FAME-FABE vs Pour point, Molar ratio of methanol-1-butanol. (left) (b) Contour Plot of FAEE-FABE Yield vs Pour Point, Molar ratio of ethanol-1-butanol (right). The reaction temperature hold at $290{ }^{\circ} \mathrm{C}$, molar ratio of camelina oil-alcohol mixtures of 1:40, reaction time of $30 \mathrm{~min}$, and the initial pressure of 500psi. 


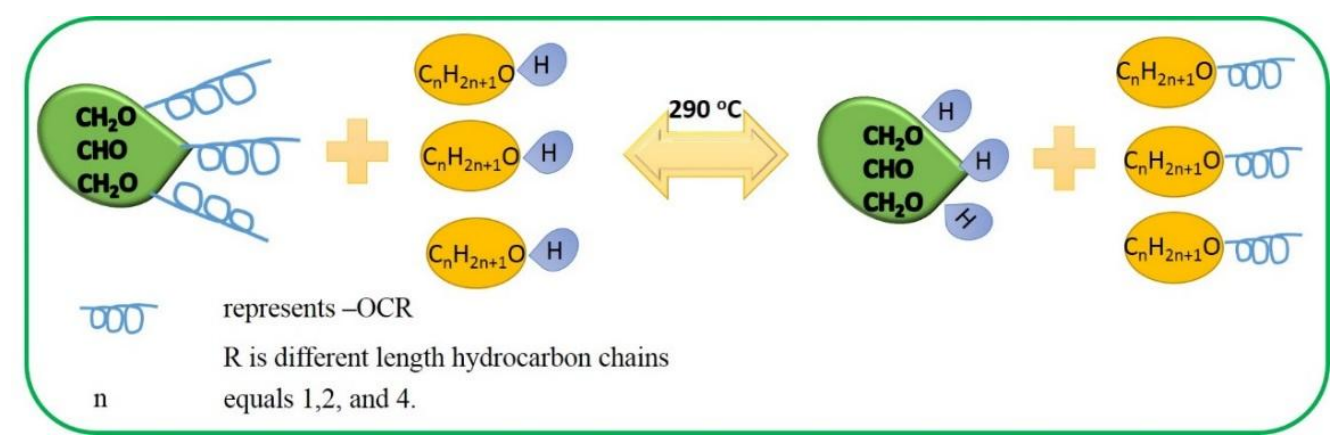

Figure 1

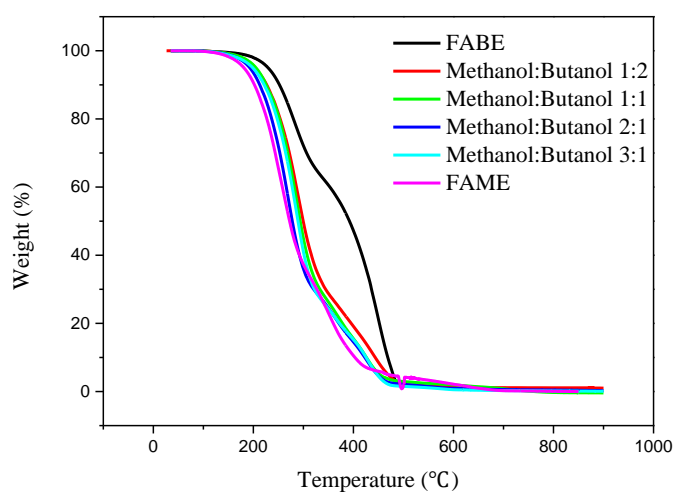

(a)

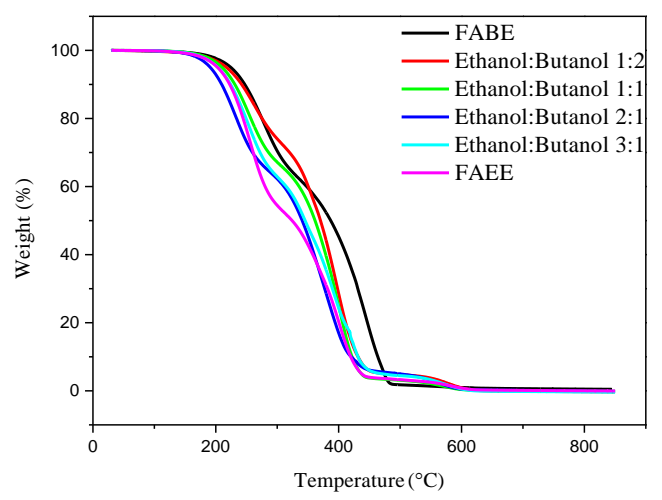

(b)

Figure 2

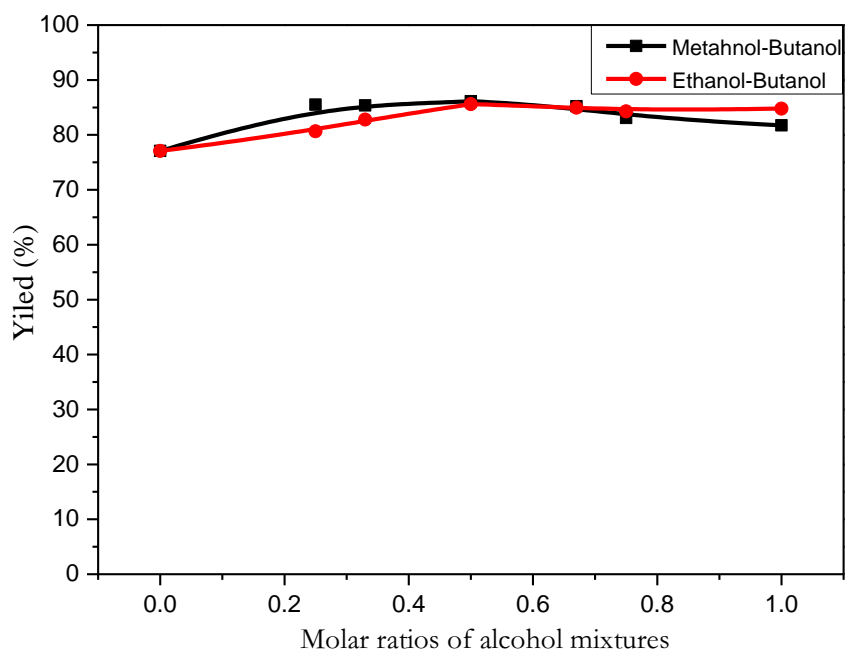

Figure 3 


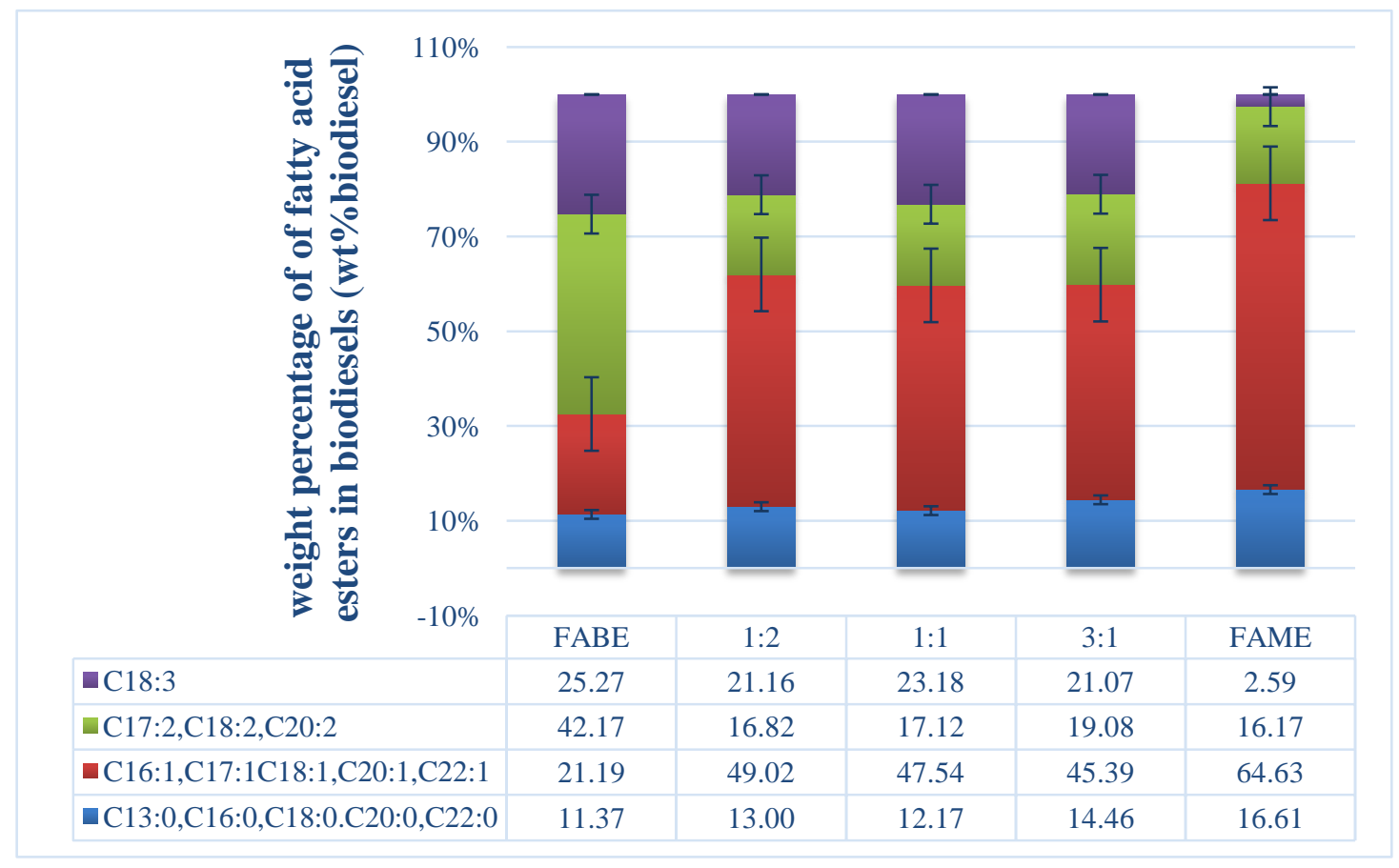

(a)

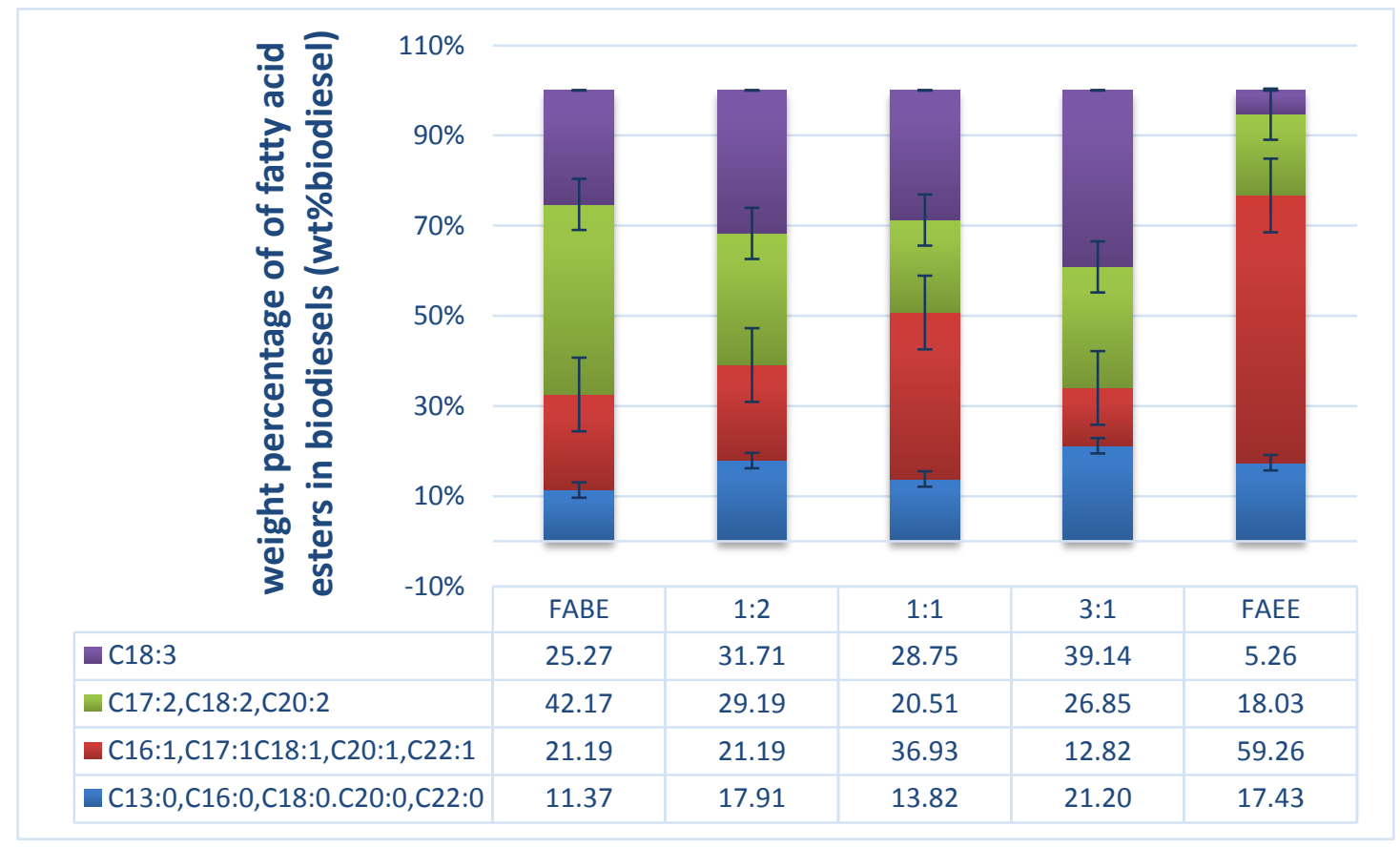

(b)

Figure 4 

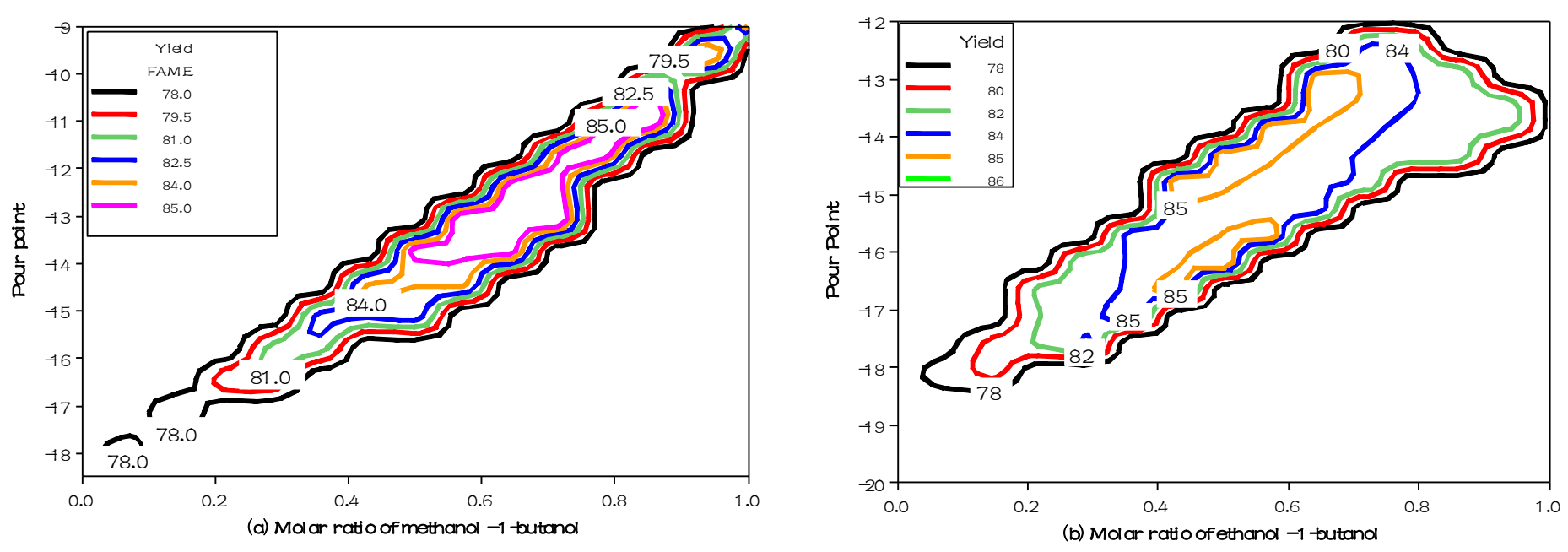

Figure 5 


\section{List of tables}

2

3 Table 1. Identified compounds of camelina sativa oil FAME-FABE biodiesels (a) and FAEE-FABE biodiesels (b) by GC-MS analysis.

5 Table 2. Mass remaining percentages at specific thermal gravity analysis temperatures.

7

Table 3. Fuel properties of FAME-FABE mixtures (a), and FAEE-FABE mixtures

8 (b).

9 
Table 1 (a)

\begin{tabular}{l|l|l}
\hline Fatty acid esters & $\begin{array}{l}\text { Common } \\
\text { name }\end{array}$ & $\begin{array}{l}\text { Retention time } \\
(\mathbf{m i n})\end{array}$ \\
\hline Tridecanoic acid, methyl ester & $\mathrm{C} 13: 0$ & 10.82 \\
Hexadecanoic acid, methyl ester & $\mathrm{C} 16: 0$ & 11.216 \\
Octadecanoic acid, methyl ester & $\mathrm{C} 18: 0$ & 13.157 \\
9-Octadecenoic acid, methyl ester, (E)- & $\mathrm{C} 18: 1$ & 13.437 \\
Hexadecanoic acid, butyl ester & $\mathrm{C} 16: 0$ & 13.53 \\
9,12-Octadecadienoic acid (Z,Z)-, methyl ester & $\mathrm{C} 18: 2$ & 13.973 \\
9,12,15-Octadecatrienoic acid, methyl ester, & $\mathrm{C} 18: 3$ & 14.678 \\
(Z,Z,Z)- & & \\
Eicosanoic acid, methyl ester & $\mathrm{C} 20: 0$ & 15.417 \\
cis-11-Eicosenoic acid, methyl ester & $\mathrm{C} 20: 1$ & 15.803 \\
Octadecanoic acid, butyl ester & $\mathrm{C} 18: 0$ & 15.891 \\
10-Octadecenoic acid, methyl ester & $\mathrm{C} 18: 1$ & 16.182 \\
cis-11,14-Eicosadienoic acid, methyl ester & $\mathrm{C} 20: 2$ & 16.415 \\
Butyl 9,12-octadecadienoate & $\mathrm{C} 18: 2$ & 16.8 \\
Butyl 9,12,15-octadecatrienoate & $\mathrm{C} 18: 3$ & 17.593 \\
Docosanoic acid, methyl ester & $\mathrm{C} 22: 0$ & 18.03 \\
13-Docosenoic acid, methyl ester, (Z)- & $\mathrm{C} 22: 1$ & 18.385 \\
cis-11-Eicosenoic acid, methyl ester & $\mathrm{C} 20: 1$ & 18.783 \\
Tricosanoic acid, methyl ester & $\mathrm{C} 23: 0$ & 19.359 \\
\hline
\end{tabular}

Table 1(b)

\begin{tabular}{l|l|l}
\hline Fatty acid esters & $\begin{array}{l}\text { Common } \\
\text { name }\end{array}$ & $\begin{array}{c}\text { Retention time } \\
\text { (min) }\end{array}$ \\
\hline Hexadecanoic acid, ethyl ester & $\mathrm{C} 16: 0$ & 11.613 \\
Hexadecanoic acid, butyl ester & $\mathrm{C} 16: 0$ & 13.524 \\
Octadecanoic acid, ethyl ester & $\mathrm{C} 18: 0$ & 13.623 \\
(E)-9-Octadecenoic acid ethyl ester & $\mathrm{C} 18: 1$ & 13.979 \\
9,12-Octadecadienoic acid, ethyl ester & $\mathrm{C} 18: 2$ & 14.439 \\
9,12,15-Octadecatrienoic acid, ethyl ester, (Z,Z,Z)- & $\mathrm{C} 18: 3$ & 15.156 \\
Octadecanoic acid, butyl ester & $\mathrm{C} 18: 0$ & 15.891 \\
Butyl 11-eicosenoate & $\mathrm{C} 20: 1$ & 16.001 \\
Eicosanoic acid, ethyl ester & $\mathrm{C} 20: 0$ & 16.415 \\
Ethyl Oleate & $\mathrm{C} 20: 1$ & 16.31 \\
Butyl 9,12-octadecadienoate & $\mathrm{C} 18: 2$ & 16.806 \\
Butyl 9,12,15-octadecatrienoate & $\mathrm{C} 18: 3$ & 17.598 \\
Ethyl 13-docosenoate & $\mathrm{C} 22: 1$ & 18.916 \\
Tricosanoic acid, methyl ester & $\mathrm{C} 23: 0$ & 19.353 \\
\hline
\end{tabular}


Table 2

\begin{tabular}{|c|c|c|c|c|c|c|c|c|c|c|c|}
\hline $\begin{array}{l}\text { Temperature } \\
\left({ }^{\circ} \mathrm{C}\right)\end{array}$ & FABE & $\begin{array}{l}\text { M-B } \\
1: 2\end{array}$ & $\begin{array}{l}\text { E-B } \\
1: 2\end{array}$ & $\begin{array}{l}\text { M-B } \\
1: 1\end{array}$ & $\begin{array}{l}\text { E-B } \\
1: 1\end{array}$ & $\begin{array}{l}\text { M-B } \\
2: 1\end{array}$ & $\begin{array}{l}\text { E-B } \\
2: 1\end{array}$ & $\begin{array}{l}\text { M-B } \\
3: 1\end{array}$ & $\begin{array}{l}\text { E-B } \\
3: 1\end{array}$ & FAME & FAEE \\
\hline 250 & $90.04 \%$ & $82.26 \%$ & $89.15 \%$ & $79.96 \%$ & $87.80 \%$ & $70.61 \%$ & $73.16 \%$ & $77.67 \%$ & $79.67 \%$ & $64.14 \%$ & $76.67 \%$ \\
\hline 400 & $47.21 \%$ & $19.11 \%$ & $28.55 \%$ & $15.50 \%$ & $24.96 \%$ & $14.56 \%$ & $17.01 \%$ & $15.25 \%$ & $24.32 \%$ & $10.54 \%$ & $20.32 \%$ \\
\hline 450 & $21.22 \%$ & $7.57 \%$ & $5.89 \%$ & $5.32 \%$ & $3.77 \%$ & $4.67 \%$ & $6.09 \%$ & $4.51 \%$ & $6.00 \%$ & $5.95 \%$ & $3.99 \%$ \\
\hline 600 & $1 \%$ & $1.23 \%$ & $0.89 \%$ & $1.95 \%$ & $0.37 \%$ & $0.92 \%$ & $0.50 \%$ & $0.53 \%$ & $0.51 \%$ & $2.14 \%$ & $0.80 \%$ \\
\hline 700 & $0.65 \%$ & $1.13 \%$ & $0.12 \%$ & $0.81 \%$ & $0.11 \%$ & $0.58 \%$ & $0.13 \%$ & $0.28 \%$ & $0.10 \%$ & $0.24 \%$ & $0.12 \%$ \\
\hline
\end{tabular}


Table 3 (a)

\begin{tabular}{lccccc}
\hline Biodiesel properties & Specific gravity & $\begin{array}{c}\text { Viscosity }\left(\mathrm{mm}^{2} / \mathrm{s}\right) \\
\text { at } 40^{\circ} \mathrm{C}\end{array}$ & $\begin{array}{c}\text { Calorific value } \\
(\mathrm{MJ} / \mathrm{Kg})\end{array}$ & $\begin{array}{c}\text { Cetane } \\
\text { number }\end{array}$ & $\begin{array}{c}\text { Pour point } \\
\left({ }^{\circ} \mathrm{C}\right)\end{array}$ \\
\hline FAME & $0.88-0.90$ & $4.25-4.36$ & 39.26 & $47.60-48.75$ & -10 to -8 \\
M-B 3:1 & 0.90 & 5.68 & 38.44 & $47.30-47.63$ & -13 to -9 \\
M-B 2:1 & 0.90 & 6.76 & 37.06 & $48.54-48.87$ & -16 to -12 \\
M-B 1:1 & 0.93 & 9.57 & 37.02 & $42.51-42.79$ & -15 to -12 \\
M-B 1:2 & 0.92 & 8.23 & 37.96 & $44.20-44.48$ & -16 to -14 \\
FABE & $0.88-0.90$ & $4.95-56.21$ & 39.97 & $49.46-49.82$ & -20 to -17 \\
Biodiesel standard & $0.87-0.90$ & $1.9-6.0$ & - & 47 min & -15 to 10 \\
(ASTM D6751-08) & & & & & \\
Testing methods & ASTM D287 & ASTM D445 & ASTM D240 & ASTM D613 & ASTM D97 \\
\hline
\end{tabular}

\section{Table 3(b)}

\begin{tabular}{lccccc}
\hline Biodiesel properties & $\begin{array}{c}\text { Specific } \\
\text { gravity }\end{array}$ & $\begin{array}{c}\text { Viscosity }\left(\mathrm{mm}^{2} / \mathrm{s}\right) \\
\text { at } 40^{\circ} \mathrm{C}\end{array}$ & $\begin{array}{c}\text { Calorific value } \\
(\mathrm{MJ} / \mathrm{Kg})\end{array}$ & $\begin{array}{c}\text { Cetane } \\
\text { number }\end{array}$ & $\begin{array}{c}\text { Pour point } \\
\left({ }^{\circ} \mathrm{C}\right)\end{array}$ \\
\hline FAEE & $0.87-0.89$ & $4.80-4.96$ & 39.60 & $51.55-51.80$ & -15 to -12 \\
E-B 3:1 & 0.92 & 8.15 & 37.43 & $42.97-43.26$ & -14 to -10 \\
E-B 2:1 & 0.92 & 8.59 & 37.70 & $44.21-44.78$ & -15 to -12 \\
E-B 1:1 & 0.93 & 9.88 & 38.20 & $42.16-42.43$ & -15 to -13 \\
E-B 1:2 & 0.93 & 15.67 & 37.86 & $43.50-43.77$ & -19 to -16 \\
FABE & $0.88-0.90$ & $4.95-5.21$ & 39.97 & $49.46-49.82$ & -20 to -17 \\
Biodiesel standard & $0.87-0.90$ & $1.9-6.0$ & - & 47 min & -15 to 10 \\
(ASTM D6751-08) & & & & & \\
Testing methods & ASTM D287 & ASTM D445 & ASTM D240 & ASTM D613 & ASTM D97 \\
\hline
\end{tabular}

